Kusbiantoro, D. · Y. Purwaningrum

\title{
Pemanfaatan kandungan metabolit sekunder pada tanaman kunyit dalam mendukung peningkatan pendapatan masyarakat
}

\section{Utilization of secondary metabolite in the turmeric plant to increase community income}

\author{
Diterima : 13 Februari 2018/Disetujui : 13 Maret 2018 / Dipublikasikan : 31 Maret 2018 \\ CDepartment of Crop Science, Padjadjaran University
}

\begin{abstract}
Curcumin is an active component that is widely contained in turmeric. In addition to protecting the liver from damage, it also works as a powerful antioxidant (capturing free radicals harmful to body cells), able toprevent the doubling of cancer cells, can reduce cholesterol and works as anti-inflammation. Recent research proves that Curcumin can also prevent colon cancer. This curcumin has been widely studied by experts both domestic and foreign as a hepatoprotector (protector of the liver from damage) and accelerate the regeneration of liver cells. The modern medic still entrusted liver therapy using Curcumin, as it is safer than using other unnatural substances. It needs a comprehensive agribusiness, steady and continuous effort to supply raw materials and sources of raw materials to be planted and developed it so its increase the value of exports and foreign exchange of Indonesia.
\end{abstract}

Keywords: Turmeric, curcumin, income

Sari. Curcumin merupakan komponen aktif yang banyak terkandung di dalam kunyit. Selain dapat melindungi hati dari kerusakan juga dapat berfungsi sebagai antioksidan yang kuat (menangkap radikal-radikal bebas yang berbahaya bagi sel tubuh), mampu menahan pelipatgandaan sel kanker, dapat menurunkan kolesterol, dan sebagai anti radang. Penelitian terakhir mem-buktikan bahwa Curcumin juga dapat mencegah kanker

\footnotetext{
Dikomunikasikan oleh Agung Karuniawan

Kusbiantoro, $\mathrm{D}^{1} \cdot$ Y. Purwaningrum ${ }^{2}$

${ }^{1}$ Program Studi Agribisnis, Fakultas Pertanian, Universitas

Islam Sumatera Utara. Jl. Karya Wisata Gedung Johor,

Medan-20144, Sumatera Utara, Indonesia

2 Program Studi Agroteknologi, Fakultas Pertanian,

Universitas Islam Sumatera Utara. Jl. Karya Wisata

Gedung Johor, Medan-20144, Sumatera Utara, Indonesia

Korespondensi : dedi.kusbiantoro@fp.uisu.ac.id
}

usus besar. Curcumin ini sudah banyak diteliti oleh para ahli baik dari luar negeri maupun dalam negeri sebagai hepatoprotektor (pelindung hati dari kerusakan) dan mempercepat regenerasi sel hati. Dunia medis modern hingga saat ini masih mempercayakan terapi hati dengan menggunakan Curcumin, karena lebih aman dibanding menggunakan zat lain yang tidak alami. Diperlukan usaha (agribisnis) yang besar, mantap dan terus menerus serta intensif penyediaan bahan baku dan sumber asal bahan bakunya untuk ditanam dan dikembangkan dengan harapan agar didapatkan produksi tanaman obat yang tinggi sehingga dapat meningkatkan nilai perdagangannya (ekspor) dan devisa Indonesia.

Kata kunci : Kunyit, curcumin, pendapatan

\section{Pendahuluan}

Tanaman memiliki dua jenis senyawa metabolit, yaitu metabolit primer dan sekunder. Metabolit primer digunakan tanaman untuk pertumbuhan, sedangkan metabolit sekunder tidak berperan secara langsung untuk pertumbuhan tanaman. Metabolit sekunder diproduksi tanaman dalam jumlah tertentu pada kondisi tercekam. Contoh metabolit sekunder di antaranya adalah antibiotik, pigmen, toksin, efektor kompetisi ekologi dan simbiosis, fero-mon, inhibitor enzim, agen immunomodulasi, reseptor antagonis dan agonis, pestisida, agen antitumor, dan promotor pertumbuhan hewan dan tumbuhan (Nofiani 2008).

Metabolit sekunder merupakan senyawa yang tidak terlibat langsung dalam pertumbuhan, perkembangan, atau reproduksi makhluk hidup. Namun, senyawa ini biasa digunakan untuk perkembangbiakan dan pertahanan 
tanaman karena umumnya senyawa metabolit sekunder bersifat racun bagi hewan, diantaranya adalah senyawa alkaloid, fenol, saponin dan terpenoid.

Senyawa metabolit sekunder banyak sekali jumlahnya. Menurut Springob dan Kutchan (2009), ada lebih dari 200.000 struktur produk alamiah atau produk metabolit sekunder, sehingga untuk memudahkan mengetahui jenis dari metabolit sekunder tersebut, perlu dibuat klasifikasinya, seperti berdasarkan sifat struktur, asal-usul biosintesis, atau lainnya.

Tanaman merupakan salah satu sumber bahan baku dalam sistem pengobatan tradisional maupun modern dan lebih dari 60\% produk farmasetik berasal dari tanaman (Jain, 2007). Diantaranya adalah Curcuma longa Linn. (sinonim Curcuma domestica Val) yang biasa disebut dengan kunyit. Kunyit termasuk ke dalam famili zingiberaceae merupakan tanaman obat dan bumbu masakan yang banyak digunakan oleh sebagian besar masyarakat di Indonesia dan India. Kunyit digunakan dalam berbagai bidang seperti kesehatan, kuliner, dan kosmetik.

Beberapa tahun terakhir penelitian secara intensif dilakukan untuk mengetahui aktivitas biologi dan aksi farmakologi dari kunyit dan ekstraknya. Daging buah kunyit yang berwarna kuning disebabkan oleh curcumin yang merupakan komponen bioaktif dari metabolit sekunder kunyit. Curcumin menunjukkan aktivitas dan potensi terapetik yang hebat, termasuk aktivitasnya sebagai antiinflamasi, antioksidan biologi, antikarsinogenik, antimutagenik, antikoagulan, antifertilitas, antidiabetik, antibakteri, antifungi, antiprotozoa, antiviral, antifibrosis, antivenom, antiulcer, hipotensig, dan hipokolesterolemia (Jain, 2007; Chattopadhyay et al. 2004).

Katekin adalah salah satu turunan dari poliphenol yang memiliki khasiat antioksidan yang tinggi. Faktor yang mempengaruhi kadar katekin adalah varietas dan klon teh, ketinggian tempat (Anjarsari I.R.D., 2016). Sama dengan halnya teh kunyit juga memiliki sifat antioksidan karena mengandung senyawa kurkumin (Setyowati A., 2013). Kurkumin adalah senyawa aktif merupakan polifenol dengan rumus kimia C21H20O6. Kunyit (Curcuma longa) termasuk salah satu tanaman rempah dan obat, habitat asli tanaman ini meliputi wilayah Asia khususnya Asia Tenggara. Penelitian tentang efek terapi kurkumin telah banyak dilakukan. Saat ini penelitian lebih difokuskan pada mekanisme efek molekulernya. Penelitian yang dilakukan oleh Weisberg dkk yang diterbitkan dalam jurnal berjudul "Dietary Curcumin Significantly Improves Obesity Associated Inflammation and Diabetes in Mouse Models of Diabesity" menunjukkan bahwa kurkumin terbukti memperbaiki inflamasi terkait obesitas dan diabetes. (Weisberg SP et al., 2008).

\section{Hasil dan Pembahasan}

Kunyit (Curcuma longa Linn. syn. Curcuma domestica Val.). Kunyit adalah salah satu jenis rempah-rempah yang banyak digunakan sebagai bumbu dalam berbagai jenis masakan. Kunyit memiliki nama latin Curcuma domestica Val. Kunyit termasuk salah satu suku tanaman temu-temuan (Zingiberaceae). Menurut Winarto (2004), dalam taksonomi tanaman kunyit dikelompokkan sebagai berikut :

$\begin{array}{ll}\text { Kingdom } & \text { : Plantae } \\ \text { Divisio } & \text { : Spermatophyta } \\ \text { Sub divisio } & \text { : Angiospermae } \\ \text { Class } & \text { : Monocotyledonae } \\ \text { Ordo } & \text { : Zingiberales } \\ \text { Family } & \text { : Zingiberaceae } \\ \text { Genus } & \text { : Curcuma } \\ \text { Species } & \text { : Curcuma domestica Val }\end{array}$

Tanaman kunyit tumbuh bercabang dengan tinggi 40-100 cm. Batang merupakan batang semu, tegak, bulat, membentuk rimpang dengan warna kekuningan dan tersusun dari pelepah daun (agak lunak). Daun tunggal, bentuk bulat telur (lanset) memanjang hingga $10-40 \mathrm{~cm}$, lebar 8-12,5 cm dan pertulangan menyirip dengan warna hijau pucat.

Distribusi tanaman. Kunyit (Curcuma domestica Vahl.) merupakan tanaman obat asli dari Asia Tenggara dan telah dikembangkan secara luas di Asia Selatan, Cina Selatan, Taiwan, Filipina dan tumbuh dengan baik di Indonesia. Tanaman tumbuh tegak mencapai tinggi 1,0 - 1,5 m. Memiliki batang semu yang dililit oleh pelepah-pelepah daun. Daun tanaman runcing dan licin dengan panjang sekitar $30 \mathrm{~cm}$ dan lebar $8 \mathrm{~cm}$. Bunga muncul dari batang semu dengan panjang sekitar $10-15 \mathrm{~cm}$. Warna bunga putih atau putih bergaris hijau dan terkadang ujung bunga berwarna merah jambu. Bagian utama dari tanaman adalah rimpangnya yang berada di dalam tanah. Rimpang ini biasanya tumbuh menjalar dan rimpang induk biasanya berbentuk elips. (Cheppy dan Fatimah, 2007) 
Deskripsi Tanaman: Warna, Keragaan Tanaman, Teknik Budidaya. Rimpang ini biasanya tumbuh menjalar dan rimpang induk berbentuk lonjong. Rimpang kunyit (Curcuma domestica rhizoma) dalam keadaan utuh atau dipotong-potong. Rimpang kunyit mempunyai bau khas aromatik, rasa agak pahit, agak pedas, lama kelamaan menimbulkan rasa tebal. Kepingan rimpangnya ringan, rapuh, berwarna kuning jingga, kuning jingga kemerahan sampai kuning jingga kecoklatan (Dirjen POM 2000).

Kandungan Senyawa Bioaktif Curcumin. Kunyit mengandung senyawa yang berkhasiat obat, yang disebut kurkuminoid yang terdiri dari kurkumin, desmetoksikumin sebanyak $10 \%$ dan bisdesmetoksikurkumin sebanyak 1-5\% dan zat-zat bermanfaat lainnya seperti minyak atsiri yang terdiri dari keton sesquiterpen, turmeron, tumeon $60 \%$, zingiberen $25 \%$, felandren, sabinen, borneol dan sineil. Kunyit juga mengandung lemak sebanyak 1-3\%, karbohidrat sebanyak $3 \%$, protein $30 \%$, pati $8 \%$, Vitamin C $45-55 \%$, dan garam-garam mineral, yaitu zat besi, fosfor, dan kalsium. (Chattopadhyay et al. 2004)

Senyawa kimia utama yang terkandung di dalam rimpang kunyit adalah minyak atsiri dan kurkuminoid. Minyak atsiri mengandung senyawa seskuiterpen alkohol, turmeron dan zingiberen, sedangkan kurkuminoid mengandung senyawa kurkumin dan turunannya (berwarna kuning) yang meliputi desmetoksi kurkumin dan bidesmetoksikurkumin. Selain itu rimpang juga mengandung senyawa gom, lemak, protein, kalsium, fosfor dan besi (Kristina et al, 2010)

Kandungan kimia kunyit terdiri atas karbohidrat $(3 \%)$, protein $(30 \%)$, lemak $(5,1 \%)$, mineral $(3,5 \%)$, dan moisture $(13,1 \%)$. Minyak esensial $(5,8 \%)$ dihasilkan dengan destilasi uap dari rimpang yaitu a-phellandrene (1\%), sabinene $(0.6 \%)$, cineol $(1 \%)$, borneol $(0.5 \%)$, zingiberene $(25 \%)$ and sesquiterpines $(53 \%)$. Curcumin (diferuloylmethane) (3-4\%) merupakan komponen aktif dari kunyit yang berperan untuk warna kuning, dan terdiri dari Curcumin I (94\%), Curcumin II (6\%) and Curcumin III $(0.3 \%)$.

Kurkuminoid adalah kelompok senyawa fenolik yang terkandung dalam rimpang tanaman famili Zingiberaceae antara lain: Curcuma longa syn. Curcuma domestica (kunyit) dan Curcuma xanthorhiza (temulawak). Curcumin mempunyai rumus molekul $\mathrm{C}_{23} \mathrm{H}_{20} \mathrm{O}_{6}$ dengan BM 368,37 serta titik lebur $183^{\circ} \mathrm{C}$, tidak larut dalam air dan eter, larut dalam etil asetat, metanol, etanol, benzena, asam asetat glasial, aseton dan alkali hidroksida (Kiko, 1983). Sifat kurkumin yang menarik adalah perubahan warna akibat perubahan $\mathrm{pH}$ lingkungan. Dalam suasana asam kurkumin berwarna kuning atau kuning jingga sedangkan dalam suasana basa berwarna merah. Hal terrsebut dapat terjadi karena adanya sistem tautomeri pada molekulnya.

Untuk mendapatkan stabilitas yang optimum dari sediaan curcuumin maka $\mathrm{pH}$ nya dipertahankan kurang dari 7. Pada $\mathrm{pH}$ lebih dari 7 kurkumin sangat tidak stabil dan mudah mengalami disosiasi (Tonnesen dan Karlsen, 1985). Sifat kurkumin yang penting adalan sensitivitasnya pada cahaya. Curcumin akan mengalami dekomposisi jika terkena cahaya. Produk degradasinya yang utama adalah asam ferulat, aldehid ferulat, dehidroksinaftalen, vinilquaikol, vanilin dan asam vanilat.

Kurkuminoid bermanfaat untuk mencegah timbulnya infeksi berbagai penyakit. Kandungan utama dari kurkuminoid adalah kurkumin yang berwarna kuning. Kandungan kurkumin di dalam kunyit berkisar 3-4\% . Curcumin atau diferuloyl methane pertama kali diisolasi pada tahun 1815. Kemudian tahun 1910, curcumin didapatkan ber-bentuk kristal dan bisa dilarutkan tahun 1913. Kurkumin tidak dapat larut dalam air, tetapi larut dalam etanol dan aceton (Kristina et al, 2010).

Mekanisme Kerja Senyawa Bioaktif. Komposisi kimia dari minyak atsiri segar, kering dan sembuh kunyit (Curcuma Longa) rimpang dari satu sumber yang dipilih. Selain itu, antioksidan dan potensi scavenging radikal yang berkorelasi dengan komposisi kimia. Komponen utama adalah ar-turmerone (21.0$30,3 \%)$, a-turmerone $(26.5-33,5 \%)$ dan $\beta$-turmerone $(18.9-21,1 \%)$. Trolox kapasitas antioksidan setara (TEAC) nilai adalah 38,9, 68,0 dan 66,9 M pada $1 \mathrm{mg}$ minyak / $\mathrm{ml}$ untuk segar, kering dan sembuh rimpang masing-masing pada uji ABTS. Nilai IC50 untuk segar, kering dan sembuh minyak rimpang untuk memuaskan radikal DPPH adalah 4,4, 3,5 dan 3,9 mg minyak $/ \mathrm{ml}$ masing-masing. Segar, kering dan sembuh rimpang minyak menunjukkan kapasitas antioksidan 358, 686 dan $638 \mathrm{mM}$ setara asam askorbat per $1 \mathrm{mg}$ minyak masing-masing. Minyak rimpang menunjukkan potensi mengurangi baik dan konsentrasi tergantung. Hal ini disimpulkan bahwa rimpang disembuhkan 
disediakan hasil yang tinggi dari minyak atsiri dengan antioksidan lumayan tinggi potensial (Dhanalakshmi Kutti Gounder, Jaganmohanrao Lingamallu, 2012).

Manfaat Curcumin Sebagai Antioksidan. Penelitian tentang efek terapi kurkumin telah banyak dilakukan. Saat ini penelitian lebih difokuskan pada mekanisme efek molekulernya. Penelitian yang dilakukan oleh Weisberg dkk yang diterbitkan dalam jurnal berjudul "Dietary Curcumin Significantly Improves Obesity Associated Inflammation and Diabetes in Mouse Models of Diabesity" menunjukkan bahwa kurkumin terbukti memperbaiki inflamasi terkait obesitas dan diabetes. (Weisberg SP et al., 2008) sama dengan halnya tanaman Jengkol merupakan salah satu tanaman yang memiliki potensi sebagai obat bahan alam. Kandungan jengkol yang bermanfaat yaitu asam amino, vitamin, mineral, juga zat lain seperti saponin, flavonoid, dan tannin sangat dibutuhkan manusia. Potensi jengkol lainnya adalah mampu menurunkan kadar gula dalam darah sehingga dapat mencegah penyakit Diabetes Mellitus (Maxiselly, Y., dkk., 2015)

Serbuk kering rhizome (turmerik) mengandung $3-5 \%$ curcumin dan dua senyawa derivatnya dalam jumlah yang kecil yaitu desmetoksicurcumin dan bisdesmetoksicurcumin, yang ketiganya sering disebut sebagai kurkuminoid (Tonessen dan Karlsen, 1995). Curcumin tidak larut dalam air tetapi larut dalam etanol atau dimetilsulfoksida (DMSO). Degradasi Curcumin tergantung pada $\mathrm{pH}$ dan berlangsung lebih cepat pada kondisi netral-basa (Aggarwal et al., 2003).

Curcumin dapat mengganggu siklus sel kanker paru A549 dan menekan pertumbuhan sel. Efek penekanan tergantung pada konsentrasi. Efek tidak hanya bergantung dari sitotoksik nonspesifik, tetapi juga dari induksi apoptosis (Zhang, et al., 2004).

Aktivitas antikanker curcumin telah banyak diteliti menggunakan berbagai pendekatan pada berbagai jenis kanker baik secara in vitro maupun in vivo. Curcumin dapat dikembangkan sebagai obat antikanker yang bagus. Aktivitas antikanker curcumin dikaitkan dengan kemampuannya sebagai penghambat COX maupun pada jalur sinyal sel, baik melalui pemacuan apoptosis maupun cell cycle arrest dengan mempengaruhi produk gen penekan tumor maupun onkogen (Meiyanto, 1999). Selain itu, dikaitkan juga dengan kemampuannya sebagai antioksidan, penghambatan karsinogenesis, penghambatan proliferasi sel, antiestrogen, dan antiangiogenesis.

Curcumin memiliki dua bentuk tautomer: keton dan enol. Struktur keton lebih dominan dalam bentuk padat, sedangkan struktur enol ditemukan dalam bentuk cairan. Senyawa turunan curcumin disebut kurkuminoid, yang hanya terdapat dua macam, yaitu desmetoksikurkumin dan bisdesmetoksikurkumin, sedangkan in vivo, curcumin akan berubah menjadi senyawa metabolit berupa dihidrokurkumin atau tetrahidrokurkumin sebelum kemudian dikonversi menjadi senyawa konjugasi monoglukoronida (Aggarwal dan Shishodia, 2006).

Serbuk kunyit mempunyai aktivitas penyembuhan luka pada pasien diabetes dan terbukti mempunyai aktivitas antimikroba dan antifungi yang signifikan. Komponen minyak atsiri, turmeron dan kurlon mempunyai daya spektrum yang luas dalam membunuh bakteri, seperti Bacillus cereus, Bacillus coagulans, Bacillus subtilis, Staphylococcus aureus, Escherichia coli, dan Pseudomonas aeruginosa dan fungi seperti Candida albicans MTCC-183 Cryptococcus neoformans MTCC-1347. (Jain. 2007). Minyak atsiri kunyit menunjukkan, aktivitas antiinflamasi pada tikus arthitis yang diinduksi ajuva, kagenan dan hialuronidase melalui penghambatan enzim tripsin dan hialuronidase (Dirjen POM 2000).

Studi farmakokinetik pada kurkumin menunjukkan bahwa kurkumin yang diberikan peroral atau intraperitonial sebagian besar dibuang melalui feses dan hanya sebagian kecil melalui urin. Hanya sejumlah kecil kurkumin yang ditemukan pada darah dari jantung, hati, dan ginjal. Kurkumin setelah dimetabolisme di hati, akan disekresikan melalui empedu (Chattopadhyay et al 2004)

Penelitian pada tahun 2004 di University of California menunjukkan bahwa kurkumin dapat menghambat penumpukan senyawa beta amiloid yang merusak pada otak penderita penyakit Alzheimer's dan juga menguraikan plak-plak yang telah ada sebelumnya. Diketahui pula bahwa kurkumin merupakan senyawa penghambat MAO-A (monoamin oksidase) yang kuat pada dosis di atas $150 \mathrm{mg} / \mathrm{kg}$. Khasiat penghambatan terhadap MAO-B ialah pada dosis di atas $550 \mathrm{mg} / \mathrm{kg}$ (Kristina et al, 2010).

Kunyit Membantu Peningkatan Pendapatan Masyarakat. Kunyit memiliki nilai ekonomi yang cukup tinggi karena manfaat yang melimpah, misalnya untuk membuat jamu, 
sebagai bumbi masak, sebagai bahan dasar kosmetik, bahkan dapat dijadikan komoditas ekspor. Peluang usaha budidaya kunyit juga sangat menjanjikan karena segmen pasar yang cukup luas. Dalam proses pemasarannya pun tidak menagalami kendala yang berarti (Prasetyo, B., 2010)

Prinsip back to nature semakin popular di era modern ini. orang meyakini hidup lebih sehat dengan memanfaatkan bahan-bahan alami. Demikian pun dalam dunia kesehatan, dengan kemajuan ilmu pengobatan, justru banyak orang berpaling ke pengobatan tradisional. Pengobatan tradisonal juga lebih murah. Obat atau ramuan untuk kasus-kasus yang umum terjadi bahkan bisa dibuat sendiri dengan bahan-bahan yang mudah diperoleh (Thomas, 1989).

Diperlukan usaha (agribisnis) yang besar, mantap dan terus menerus serta intensif penyediaan bahan baku dan sumber asal bahan bakunya untuk ditanam dan dikembangkan dengan harapan agar didapatkan produksi tanaman obat yang tinggi sehingga dapat meningkatkan nilai perdagangannya (ekspor) dan devisa Negara Indonesia. Untuk itu hingga tahun 2010 Indonesia menargetkan nilai perdagangannya dapat mencapai $\mathrm{Rp} 8$ trilliun (Rozanna, 2007), caranya dengan mengembangkan tanaman obat yang prospektif tidak hanya secara ekstensif saja bahkan harus intensif dengan pasca panen dan pemasaran yang efektif atau dapat dikatakan melalui sistem agribisnis yang dapat dilakukan oleh semua fihak (individu, kelompok, industriawan) sehingga akan meningkatkan pendapatan tidak hanya para petani saja bahkan meningkatkan pendapatan (devisa) negara, karena manfaat usaha ini menyangkut 5 tujuan, yaitu untuk bisnis, kuratif, promotif, preventif dan artistic (Martodireso dan Widodo AS, 2002; Priyono, 2006; Rozanna, 2007).

\section{Kesimpulan}

1. Kunyit berkhasiat obat karena mengandung kurkuminoid yang terdiri dari kurkumin, desmetoksikumin sebanyak $10 \%$ dan bisdesmetoksikurkumin sebanyak 1-5\%, minyak atsiri yang terdiri dari Keton sesquiterpen, turmeron, tumeon $60 \%$, zingiberen $25 \%$, felandren, sabinen, borneol dan sineil. Kunyit juga mengandung lemak 1-3\%, karbohidrat $3 \%$, protein $30 \%$, pati $8 \%$, Vitamin C $45-55 \%$, dan garam-garam mineral, seperti zat besi, fosfor, dan kalsium.

2. Kandungan senyawa metabolit sekunder tanaman kunyit bermanfaat sebagai antioksidan dan antikanker.

3. Kandungan metabolit sekunder kunyit pada rimpang segar lebih tinggi dibandingkan rimpang kering. Demikian pula kandungan minyak atsiridan oleoresin etanol pada rimpang segar memiliki sifat antioksidan lebih tinggi dibandingkan rimpang kering.

4. Diperlukan usaha (agribisnis) yang besar, mantap dan terus menerus serta intensif penyediaan bahan baku dan sumber asal bahan bakunya untuk ditanam dan dikembangkan untuk mencapai produksi tanaman obat yang tinggi sehingga dapat meningkatkan nilai perdagangannya (ekspor) dan devisa Indonesia

\section{Daftar Pustaka}

Anjarsari, 2016. Katekin teh Indonesia : prospek dan manfaatnya. Jurnal Kultivasi Vol. 15 (2) Agustus 2016. Departemen Budidaya Pertanian. Fakultas Pertanian Universitas Padjajaran.

Chattopadhyay I, Biswas K, Bandyopadhyay U, Banerjee RK. 2004. Tumeric and curcumin; biological actions and medicinal applications. Current Sci. 87 (1): 44-53

Cheppy Syukur dan Sitti Fatimah. 2007. Manfaat Kunyit Sebagai Penguat Daya Ingat (Anti Alzheimer). Warta Puslitbangbun Vol 13 No. 2, Agustus 2007. http://www.balitro.com

Dhanalakshmi Kutti Gounder, Jaganmohanrao Lingamallu. 2012. Comparison of chemical composition and antioxidant potential of volatile oil from fresh, dried and cured turmeric (Curcuma longa) rhizomes. Industrial Crop and Product 38 (2012) 124-131. http://www.elsevier.com/locate/indrocrop

(Dirjen POM) Dirjen Pengawasan Obat dan Makanan. 2000. Acuan sediaan herbal. Jakarta : Departemen Kesehatan Republik Indonesia.

G. Singh, I.P.S. Kapoor, Pratibha Singh, Carola S. de Heluani, Marina P. de Lampasona, Cesar A.N. Catalan. 2010. Comparative study of chemical composition and antioxidant activity of fresh and dry rhizomes 
of turmeric (Curcuma longa Linn.) Food and Chemical Toxicology 48 (2010) 1026-1031. http://www.elsevier.com/locate/food chemtox

Jain S. 2007. PHCOG MAG : Plant Review Recent Trend in Curcuma Longa Linn. Pharmacognosy Reviews. Vol 1. Issue 1.

Kristina NN, Rita Noveriza, Siti Fatimah Syahid dan Molide Rizal. 2010. Peluang Peningkatan Kadar Kurkumin pada Tanaman Kunyit dan Temulawak. Balai Penelitian Tanaman Obat dan Aromatik, Bogor. http://www.balitro.com

Maxiselly, Y., A. Ismail., S. Rosniawaty., I.R.D. Anjarsari., 2015. Skrining Fitokimia Cangkang dan Kulit Batang Tanaman Jengkol Asal Ciamis Jawa Barat Sebagai Inisiasi Obat Diabetes Mellitus Berbahan Alam. J. Kutivasi Vol. 14, No. 2, Oktober 2015. Departemen Budidaya Pertanian. Fakultas Pertanian. Universitas Padjajaran.

Nofiani, R. 2008. Artikel Ulas Balik: Urgensi dan Mekanisme Biosintesis Metabolit Sekunder Mikroba Laut. Jurnal Natur Indonesia 10(2):120-125.
Prasetyo, B., 2010. Peluang Top Usaha Agribisnis. Penerbit CV. Andi Offset. Yogyakarta.

Setyowati, A., Chatarina Lilis Suryani., 2013. Peningkatan Kadar Kurkuminoid dan Aktivitas Antioksidan Minuman Instan Temulawak dan Kunyit. Jurnal Agritech Vol. 33, No. 4, November 2013. Fakultas Teknologi Pertanian. Univ. Gadjah Mada.

Shepo Shi1, Hiroyuki Morita1, Kiyofumi Wanibuchi1, Yuusuke Mizuuchi1, Hiroshi Noguchi and Ikuro Abe. 2008. Enzymatic Synthesis of Plant Polyketides. Current Organic Synthesis, Vol. 5 N0. 3.

Thomas A.N.S., 1989. Tanaman Obat Tradisonal 1. Penerbit Kanisius.

Weisberg SP, Leibel R, Tortoriello DV. (2008) Dietary Curcumin Significantly Improves Obesity-Associated Inflammation and Diabetes in Mouse Models of Diabesity. Endocrinology. 149(7) : 3549 - 58.

Winarto, W.P., Tim Lentera, 2004. Khasiat dan Manfaat Kunyit. Penerbit Agromedia Pustaka. Jakarta. 